IFAS Extension

\title{
Natural Area Weeds: Old World Climbing Fern (Lygodium microphyllum) ${ }^{1}$
}

\author{
Kenneth A. Langeland and Jeffery Hutchinson ${ }^{2}$
}

Nonnative species make up 33\% $(1,419)$ of all the plants found growing out of cultivation in Florida (Wunderlin 1998). These plants were introduced to Florida accidentally or for agricultural or landscape purposes and then became naturalized (able to reproduce out of cultivation). The Florida Exotic Pest Plant Council (FLEPPC) considers 152 of these naturalized plants to be invasive to some degree because they are altering native plant communities by displacing native species, changing community structures or ecological functions, or hybridizing with native plant species (2011).

The FLEPPC considers Old World climbing fern to be invasive. Old World climbing fern is also regulated (possession, propagation, sale, and transportation) by laws of the Florida Department of Agriculture and Consumer Services (FDACS) as a Florida Noxious Weed (5B-57.007 FAC) and by the United States Department of Agriculture (USDA) as a Federal Noxious Weed. It may be the most serious threat to Florida's natural areas.

\section{Distribution and Spread}

Native to Africa, Asia, and Australia, Old World climbing fern (OWCF) is a newcomer to Florida that has spread at an alarming rate since its introduction. The first record in

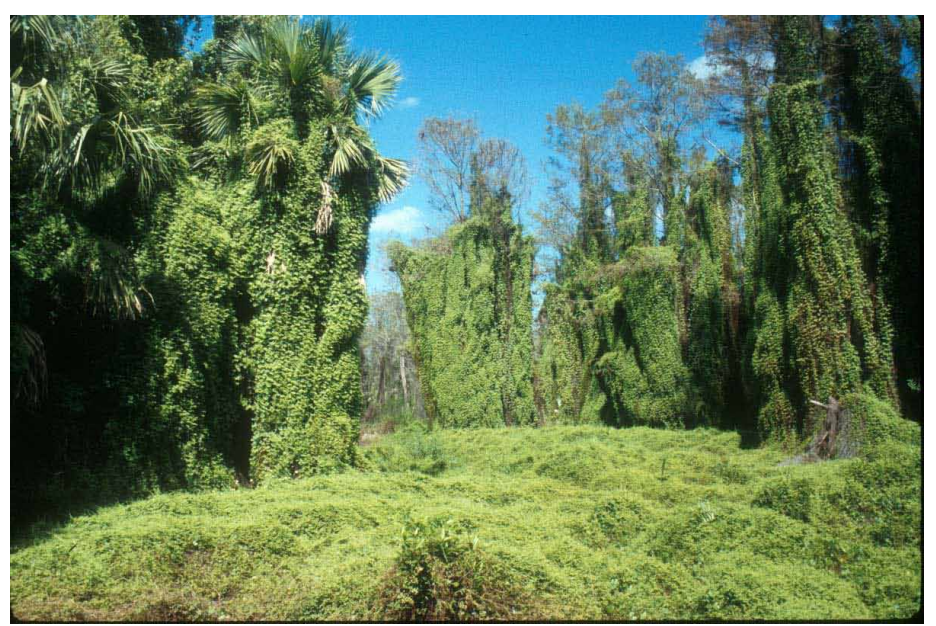

Figure 1. Old World climbing fern spreads along the ground, over shrubs, and climbs by twining around other structures, such as trees and vines.

Florida was collected from a plant in cultivation at a Delray Beach nursery in 1958 (University of Florida Herbarium record). Subsequently, a collection was made from the wild in Martin County in 1960 (Florida State University Herbarium record), and two additional collections were made from the wild in Martin County in 1965 (University of Florida Herbarium record). By 1978, it was well established and had already affected native vegetation by smothering

1. This document is SS-AGR-21, one of a series of the Agronomy Department, Florida Cooperative Extension Service, Institute of Food and Agricultural Sciences, University of Florida. Original publication date August 2001. Revised February 2013. Visit the EDIS website at http://edis.ifas.ufl.edu.

2. K. A. Langeland, professor, Agronomy Department; and Jeffery Hutchinson, former graduate research assistant, Center for Aquatic and Invasive Plants; Florida Cooperative Extension Service, Institute of Food and Agricultural Sciences, University of Florida, Gainesville, FL 32611.

The use of trade names in this publication is solely for the purpose of providing specific information. UF/IFAS does not guarantee or warranty the products named, and references to them in this publication do not signify our approval to the exclusion of other products of suitable composition. Use herbicides safely. Read and follow directions on the manufacturer's label.

The Institute of Food and Agricultural Sciences (IFAS) is an Equal Opportunity Institution authorized to provide research, educational information and other services only to individuals and institutions that function with non-discrimination with respect to race, creed, color, religion, age, disability, sex, sexual orientation, marital status, national origin, political opinions or affiliations. U.S. Department of Agriculture, Cooperative Extension Service, University of Florida, IFAS, Florida A\&M University Cooperative Extension Program, and Boards of County Commissioners Cooperating. Nick T. Place, Dean 
shrubby and herbaceous plants in southern Florida (Nauman and Austin 1978).

New OWCF populations are found in areas far from existing populations because the fern can reproduce by winddispersed spores. Spores are produced year-round in South Florida, and a single fertile leaflet can produce up to 28,600 spores, with each spore capable of starting a new population at a distant location (Lott et al. 2003; Volin et al. 2004). Area coverage of the fern increased from 27,000 acres in 1993 to 122,787 acres in 2005 (Amy Ferriter, South Florida Water Management District, personal communication).

The most northern distribution of OWCF was recorded in Orange County (Pemberton 2003). Occurrences now extend from the southern-most peninsular of Florida to Hernando County on the Gulf Coast and Duval County on the Atlantic Coast (EDDMapS 2012). OWCF occurrences verified by herbarium-vouchered specimens are reported by the University of South Florida Institute for Systematic Botany and can be accessed at http://www.florida.plantatlas. usf.edu (Wunderlin and Hansen 2008).

The Central Florida Lygodium Strategy (CFLS) is a program coordinated by The Nature Conservancy to stop the northward spread of OWCF. CFLS coordinates quick and effective treatment of newly reported OWCF occurrences along a line from northern Pinellas and Pasco Counties on the west coast northeast to northern Volusia and Flagler Counties on the east coast. Funding is available to treat private lands in the northernmost extent of the plant's range in central Florida to complement treatment efforts on public conservation lands. To find out more about CFLS, visit the program's website at http://www.nature.org/ centralfloridainvasives.

\section{Impacts to Natural Areas}

OWCF climbs into the tree canopy and competes with canopy trees and understory vegetation for light (Figure 1). It can completely engulf Everglade tree islands (Figure 2), pinelands, and cypress swamps, and spreads across open wetland marshes. It can kill mature trees along with their associated epiphytic orchids and bromeliads, and smother understory vegetation, preventing regeneration of the native plant community. As time progresses, a thick mat of old fern material accumulates on the ground, severely altering the habitat. When fire occurs, the fern carries fire into the tree canopy, causing greater damage and transporting fire through wet areas that otherwise present a boundary to the spread of fire. Rare plant species, such as the tropical curlygrass fern (Actinostachys pennula) and thin-leaved vanilla orchid (Vanilla mexicana), are threatened in their last remaining habitats, such as northern Everglade tree islands and coastal bay swamps. However, the highest potential for significant damage to native plant populations is in areas such as Fakahatchee Strand State Preserve, Everglades National Park, and Big Pine Key National Wildlife Refuge, where numerous rare plants occur.

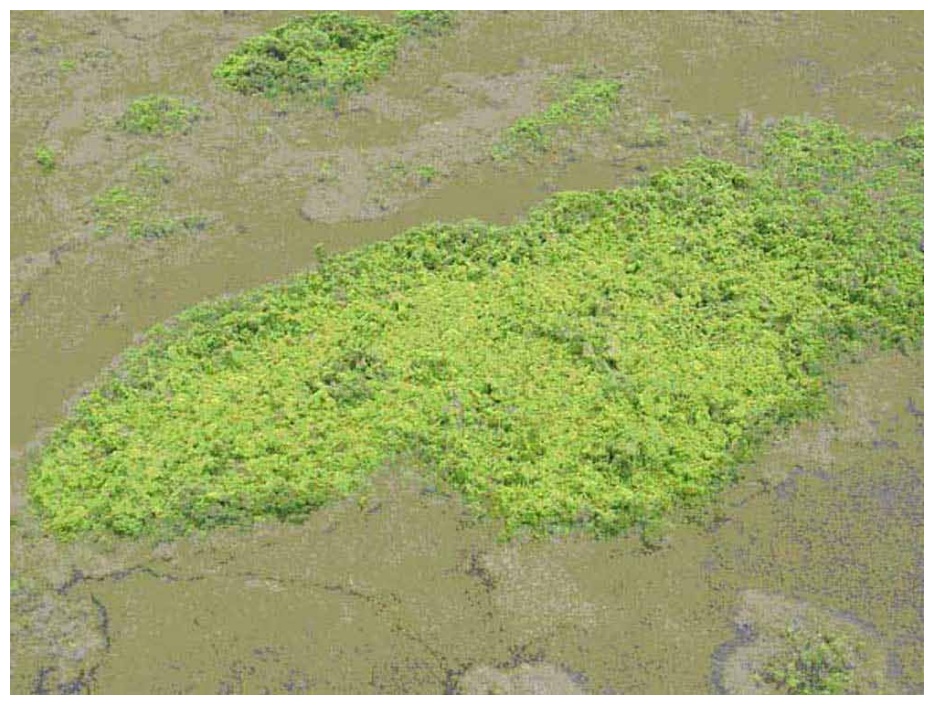

Figure 2. Old World climbing fern smothering a tree island in the northern section of the Arthur R. Marshall Loxahatchee National Wildlife Refuge in Palm Beach County.

\section{How to Recognize Old World Climbing Fern}

OWCF plants consist of long fronds (up to 90 feet long) that spread along the ground, over shrubs, or climb by twining around other structures, such as trees and other vines (Figure 1). Rhizomes (underground stems) and rachis (main stem of the frond) are dark brown to black and wiry. Leafy branches (pinnae, Figure 3 ) off the rachis are 2-5 inches long with several pairs of leaflets (pinnules). Fertile leaflets (Figure 4) are fringed with tiny lobes of enrolled leaf tissue along the leaf margin that cover the reproductive tissues.

\section{Management}

Prescribed fire, flooding (water level management), biological controls, and herbicides have been investigated as tools for integrated management of OWCF (Hutchinson et al. 2006). Fire can reduce OWCF in certain habitats but can also result in colonization by other nonnative plant species (Hutchinson and Langeland 2010). Prescribed fire alone or in most instances is not an acceptable management tool for OWCF (Hutchinson et al. 2006). OWCF grows in moist 


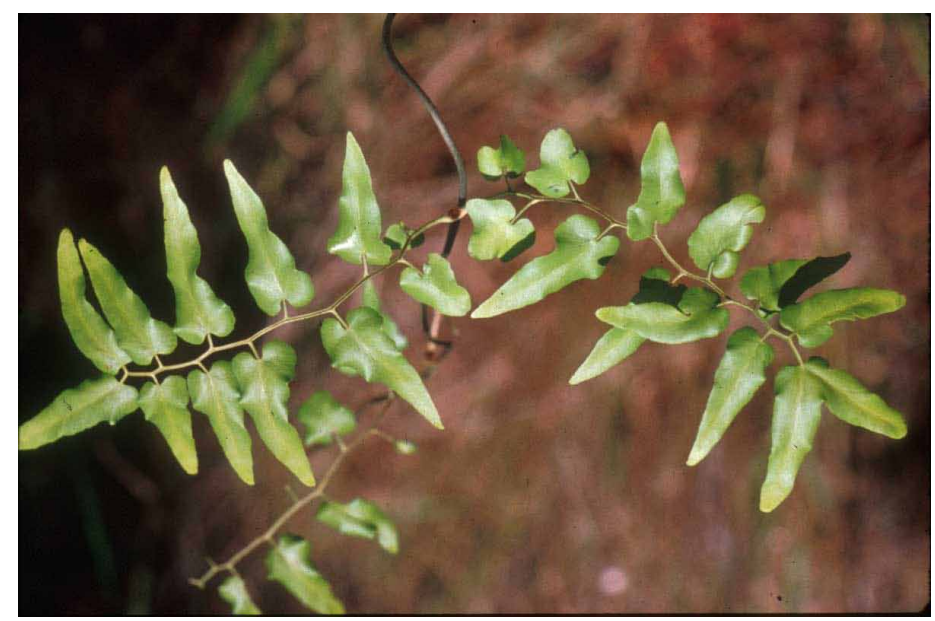

Figure 3. Leafy branches (pinnae) of Old World climbing fern are 2-5 inches long with several pairs of leaflets (pinnules).

Credits: Richard Roberts

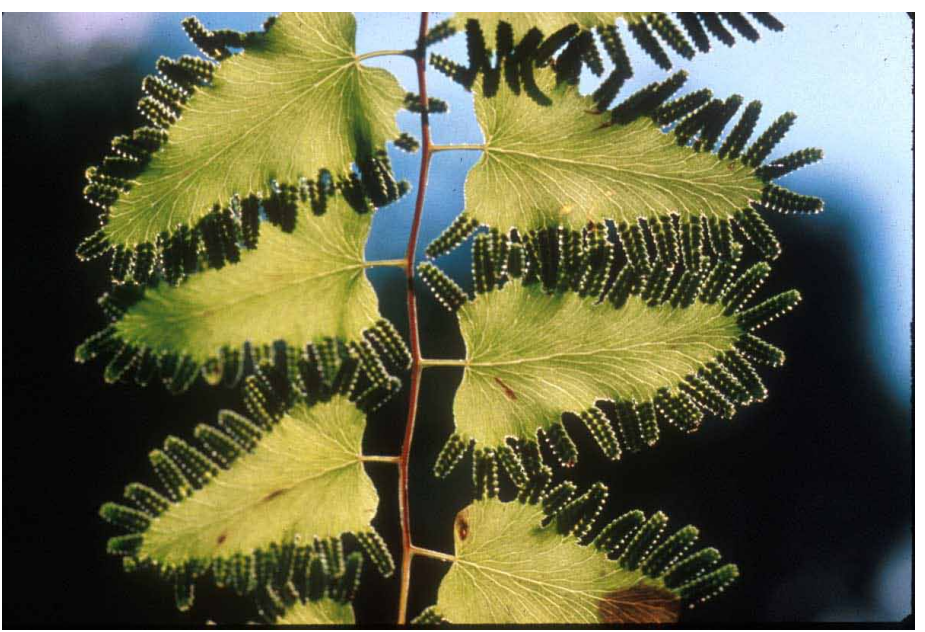

Figure 4. Fertile leaflets (pinnules) of Old World climbing fern are fringed with tiny lobes of enrolled leaf tissue along the leaf margin that cover the reproductive tissues.

Credits: Richard Roberts

habitats, so water level interval and duration can affect certain life stages; however, flooding has not been found to be a predictable management method (Hutchinson et al. 2006). Since the late 1990s, when OWCF serious management efforts began, herbicides have been used to manage OWCF and biological controls have been released and are being monitored.

\section{Herbicides}

Herbicide products that contain the active ingredients glyphosate, triclopyr, metsulfuron, and imazapic are active against OWCF. Two years after three consecutive applications (spot application with backpack sprayer) these herbicides, alone and in combination, provided similar control of OWCF (Hutchinson and Langeland, unpublished data). The herbicide product used for a specific management project depends on the herbicide characteristics, other factors (e.g., nontarget species present), and site conditions (e.g., presence or absence of standing water). Imazapic is not used because no product is registered for application to water. Triclopyr is not commonly used, especially for broadcast application, because of the spectrum of nontarget species that it affects. Glyphosate and metsulfuron are the most commonly used active ingredients because they have an appropriate selectivity spectrum and are contained in products labeled for use over water. There have been concerns about resistant OWCF populations developing as a response to repeat use of glyphosate and metsulfuron (Hutchinson, MacDonald, and Langeland 2007). Use of glyphosate and metsulfuron, along with triclopyr, should be alternated when possible to minimize the potential for development of resistance.

Expansive OWCF populations are treated initially by helicopter. Small and scattered populations (early detections and following initial aerial applications) are spot treated, usually with a backpack sprayer or hand-held application equipment. If fronds extend up into trees where herbicide cannot be applied to all the foliage, the fronds are cut at about waist height, and herbicide is applied to the lower (rooted) portion. Treated populations should be monitored for regrowth and retreated as necessary. Treated sites should be revisited a minimum of every 6 months following treatment. During site visits, all regrowth needs to be treated.

Herbicide applications to OWCF on Everglade tree islands have shown approximately $87 \%$ reduction in coverage (one year post treatment) after a single aerial application of either 3.75 or $7.5 \mathrm{pt}$ Rodeo herbicide (4 lb glyphosate acid per gal)/ac. A greater reduction of approximately $99 \%$ was observed after aerial application of either 1.0 or $2.0 \mathrm{oz}$ Escort XP (60\% metsulfuron)/ac (Hutchinson and Langeland 2012). Approximately $89 \%$ control was maintained after two consecutive annual ground treatments (backpack sprayer) with a solution containing either $2 \%$ or $4 \%$ Rodeo to those islands initially treated with Rodeo. Approximately $99 \%$ reduction was maintained after two consecutive years of ground treatments with a solution equivalent to either 0.07 or $1.40 \mathrm{oz}$ Escort XP/100 gal of water $(0.05$ or $1.0 \mathrm{~g} / \mathrm{L})$ to those islands initially treated with Escort XP.

Three years after the initial aerial applications and subsequent ground applications, dahoon holly (Ilex cassine) populations, though damaged, were not decreased by either Rodeo or Escort XP. Swamp bay (Persea palustris) and wax myrtle (Myrica cerifera) were susceptible to Rodeo but tolerant to Escort XP. Myrsine (Rapanae punctata) was susceptible to Escort XP and somewhat tolerant to Rodeo. 
Operationally, large, continuous OWCF populations are treated by helicopter with a glyphoste- or metsulfuroncontaining product (LeRoy Rodgers and Steve Smith, personal communication). Because these treatments are usually applied over water, a product labeled for aquatic application is usually used. A glyphosate-containing product that contains $4 \mathrm{lb}$ glyphosate acid per gal is applied at a rate of $7.5 \mathrm{pt}$ per acre during the season when nontarget woody species such as cypress are dormant. A product that contains $60 \%$ active ingredient metsulfuron is applied at a rate of 1-2 oz product per acre when tolerant woody species are present. The metsulfuron-containing product Escort XP is labeled for application to sites where water is present.

Following initial aerial application, spot treatment with 3\% solution of glyphosate-containing product (4 lb glyphosate acid per gal) alone or in combination with one oz of $60 \%$ metsulfuron-containing product is necessary on a one- to two-year cycle, depending on environmental conditions. While lower concentrations of glyphosate can be effective, control is more consistent using a $3 \%$ solution, an important and cost-effective consideration when treating OWCF in remote locations that are costly to access.

\section{Biological Control*}

In February 2005, a defoliating moth, Austromusotima camptonozale (Figure 5), was released in southeast Florida as a biocontrol for OWCF fern but failed to establish in any of the release range. Another species of defoliating moth, Neomusotima conspurcatalis (Figure 6), has established from releases made in 2008 and 2009. Populations are thriving in several areas and have spread to other points beyond the initial releases. Work is currently being conducted to determine the field life history of $N$. conspurcatalis and its effect on OWCF. Investigators are also looking at why $A$. camptonozale failed to establish, whereas the closely related species $N$. conspurcatalis has succeeded in this critical first step.

\section{A leaf-galling mite Floracarus perrepae (Figure 8) was} released in 2007, and it has also established in the Jupiter, Florida area. Two more insects are currently being tested for future releases: another defoliating moth within the same family as the two released moths and a sawfly whose larvae are heavy defoliators. A discussion of these efforts is presented in the "Lygodium Management Plan," available at http://fleppc.org.

${ }^{*}$ Biological control information provided by Melissa C. Smith, PhD, research ecologist, USDA-ARS Invasive Plant Research Lab, Fort Lauderdale, FL.

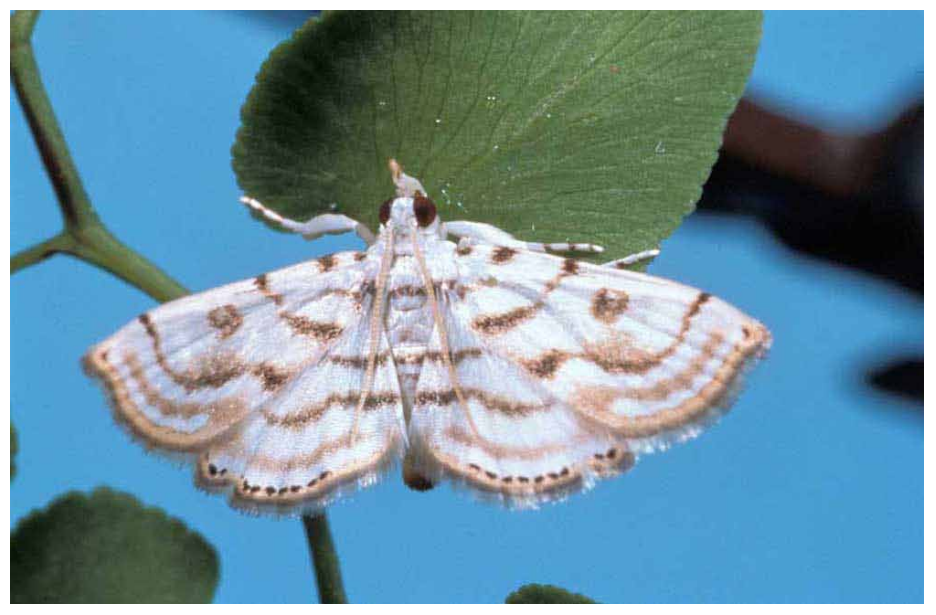

Figure 5. The defoliating moth Austromusotima camptonozale was released in February 2005 to control OWCF but failed to establish in the release range.

Credits: USDA-ARS

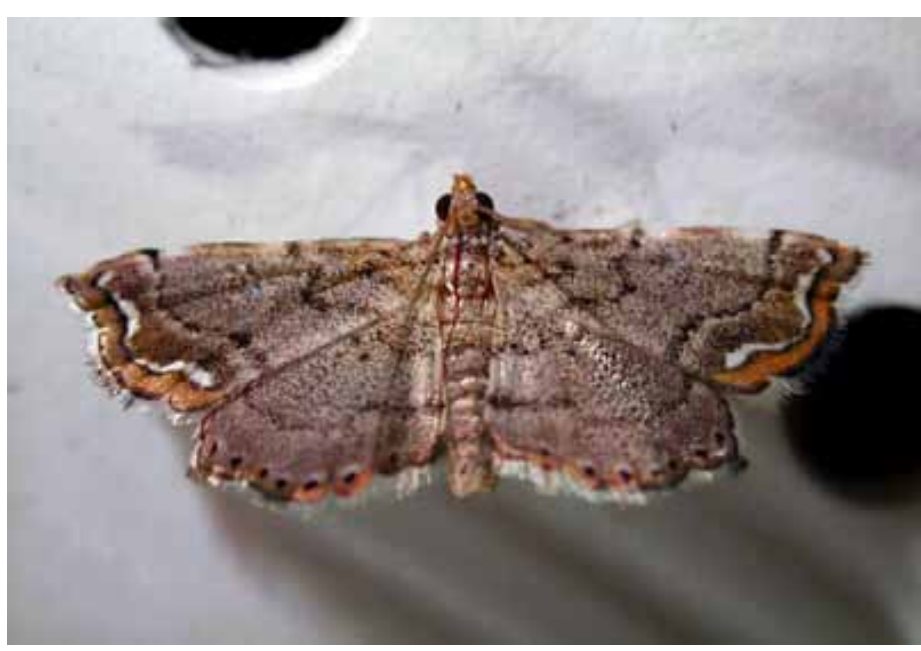

Figure 6. Neomusotima conspurcatalis adult was released in 2008 and 2009. It is established and thriving in several areas.

Credits: R. Pemberton, USDA-ARS

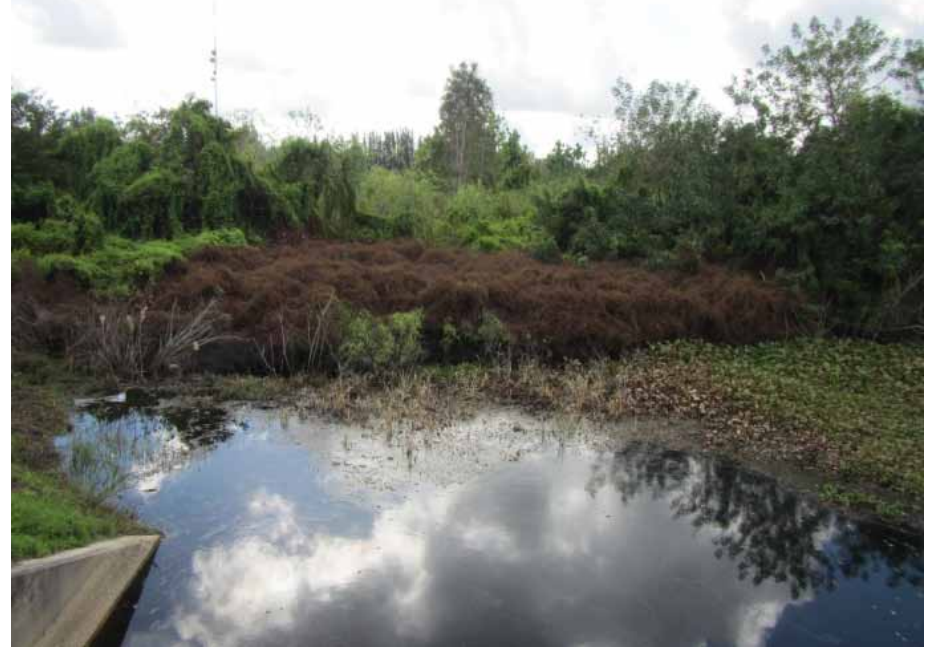

Figure 7. Feeding damage from Neomusotima conspurcatalis larvae. Credits: R. Pemberton, USDA-ARS 


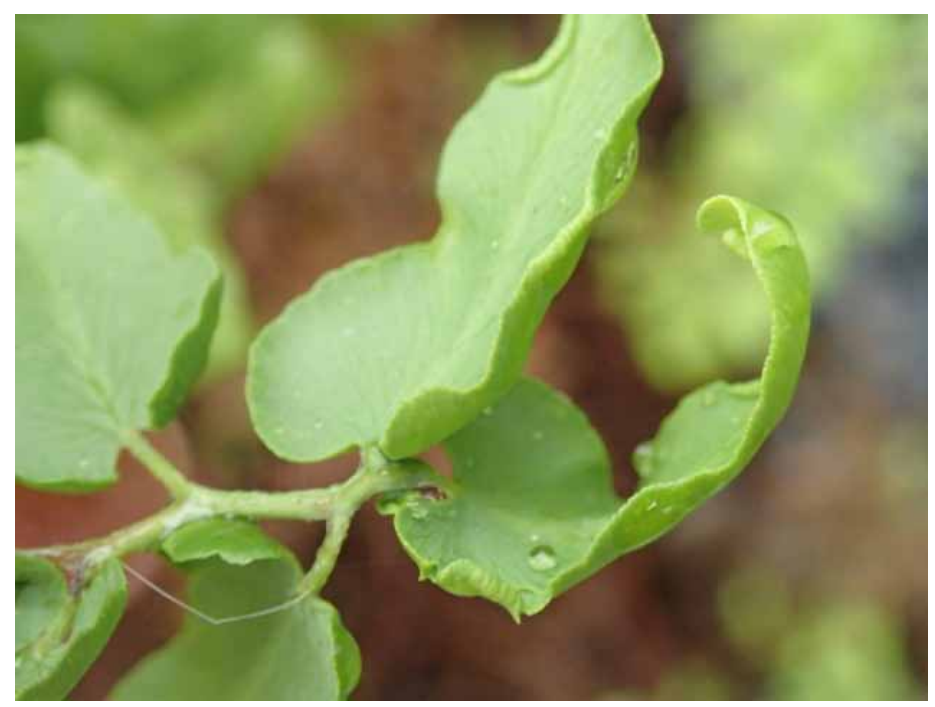

Figure 8. Leaf galling/rolling from Lygodium mite, Floracarus perrepae. Credits: M. C. Smith, USDA-ARS

\section{What You Can Do}

Citizens who want to help protect Florida's natural areas from OWCF should become familiar with how to identify it, be on the lookout, and teach others about the problem. If you find new populations of OWCF on public property, contact the property manager or appropriate agency such as a county environmental department, a Water Management District, or the Florida Department of Environmental Protection.

If you find OWCF on your own property, pull it up by the roots or spray it with herbicide. Monitor and retreat if regrowth occurs. Homeowners can purchase glyphosatecontaining herbicide in small quantities from retail garden supply stores. Do not dispose of Old World climbing fern in such a way that will cause further spread.

\section{References}

Early Detection and Distribution and Mapping System (EDDMapS). 2012. The University of Georgia - Center for Invasive Species and Ecosystem Health. Accessed December 2012. http://www.eddmaps.org.

Florida Exotic Pest Plant Council (FLEPPC). 2011. Florida Exotic Pest Plant Council's 2011 List of Invasive Plant Species. http://www.fleppc.org/list/list.htm.

Hutchinson, J. T., and K. A. Langeland. 2012. "Repeated Herbicide Application for Control of Old World Climbing Fern (Lygodium microphyllum) and the Effects on Nontarget Vegetation on Everglade Tree Islands." Invasive Plant Sci. and Manage. 5(4):477-486.
Hutchinson, J. T., and K. A. Langeland. 2010. "Monitoring of Applied Management Techniques to Control Old World Climbing Fern (Lygodium microphyllum) in Disturbed Habitat." Florida Scientist 73(3/4):262-273.

Hutchinson, J., A. Ferriter, K. Serbesof-King, K. Langeland, and L. Rodgers. 2006. "Old World Climbing Fern (Lygodium microphyllum) Management Plan for Florida." Florida Exotic Pest Plant Council. http://www.fleppc.org/ Manage_Plans/Lygo_micro_plan.pdf.

Hutchinson, J. T., G. E. MacDonald, and K. A. Langeland. 2007. "The Potential for Herbicide Resistance in Nonnative Plants in Florida's Natural Areas." Nat. Areas J. 26(3):258-263.

Lott, M. S., J. C. Volin, R. W. Pemberton, and D. F. Austin. 2003. "The Reproductive Biology of the Invasive Ferns Lygodium microphyllum and L. japonicum (Schizaeaceae): Implications for Invasive Potential." American Journal of Botany 90(8):1144-1152.

Nauman, C. E., and D.F. Austin. 1978. "Spread of the Exotic Fern Lygodium microphyllum in Florida." Amer. Fern J. 68(3):65-66.

Pemberton, R. W. 2003. "Northward Range Extension in Florida of the Invasive Fern Lygodium microphyllum (Lygodiaceae)." Sida 20:1759-1761.

Volin, J. C., M. S. Lott, J. D. Muss, and D. Owen. 2004. "Predicting Rapid Invasion of the Florida Everglades by Old World Climbing Fern (Lygodium microphyllum)." Diversity and Distributions 10(5-6):439-446.

Wunderlin, R. P. 1998. Guide to the Vascular Plants of Florida. Gainesville: University of Florida Press.

Wunderlin, R. P., and B. F. Hansen. 2008. Atlas of Florida Vascular Plants. Developed by S. M. Landry and K. N. Campbell for Florida Center for Community Design and Research. Tampa: University of South Florida Institute for Systematic Botany. http://www.plantatlas.usf.edu/. 
Table 1. Herbicide use for controlling Old World climbing fern.

\begin{tabular}{|c|c|c|}
\hline Herbicide & Use rates & Comments \\
\hline $\begin{array}{l}\text { Glyphosate } \\
4 l b \mathrm{ae}^{1 / g a l}\end{array}$ & $\begin{array}{l}\text { Spray to wet: } 2 \%-3 \% \\
\text { Aerial: } 5-7.5 \mathrm{pt} / \mathrm{ac}\end{array}$ & $\begin{array}{l}\text { Products registered for aquatic use. Symptoms } \\
\text { evident within three weeks after application. Broad } \\
\text { spectrum, some hardwoods tolerant depending on } \\
\text { application timing. }\end{array}$ \\
\hline $\begin{array}{l}\text { Imazapic } \\
2 \mathrm{lb} \text { ae/gal }\end{array}$ & $\begin{array}{l}\text { Spray to wet: } 0.32 \% \\
\text { Aerial: No information }\end{array}$ & $\begin{array}{l}\text { No products registered for aquatic use. Symptoms } \\
\text { evident within three weeks after application. } \\
\text { High degree of selectivity. }\end{array}$ \\
\hline $\begin{array}{l}\text { Metsulfuron } \\
60 \%\end{array}$ & $\begin{array}{l}\text { Spray to wet: .07-1.4 oz/100 gal } \\
\text { Aerial: } 1-2 \text { oz/ac }\end{array}$ & $\begin{array}{l}\text { Product registered for aquatic application. } \\
\text { Symptoms may not be evident for up to three } \\
\text { months. } \\
\text { High degree of selectivity. }\end{array}$ \\
\hline $\begin{array}{l}\text { Triclopyr amine } \\
\text { 3lb ae/gal }\end{array}$ & $\begin{array}{l}\text { Spray to wet: } 0.5 \% \\
\text { Aerial: NA }\end{array}$ & $\begin{array}{l}\text { Products registered for aquatic use. Broad spectrum } \\
\text { on broadleaf plants and hardwoods. } \\
\text { Symptoms evident within days. }\end{array}$ \\
\hline
\end{tabular}

